\title{
3 次元河道内地形測定における 水域データの取り扱いに関する研究 WATERS DATA TREATMENT ON 3-DIMENSIONAL MEASUREMENT OF THE LANDFORM OF THE RIVERBED
}

\author{
松本健作 1 名倉 裕 $2 \cdot$ 玉置晴朗 3 ・ 小葉竹重機 4 ・清水義彦 5 ・秋山圭史郎 6 \\ Kensaku MATSUMOTO, Hiroshi NAGURA, Haruo TAMAKI, Shigeki KOBATAKE, Yoshihiko SHIMIZU, \\ Keishirou AKIYAMA

\footnotetext{
1 正会員 博(工) 群馬大学工学部建設工学科（テ376-8515 群馬県桐生市天神町 1-5-1)

2 非会員 株式会社数理設計研究所（テ373-0019 群馬県太田市吉沢町太田リサーチパーク 1-101）

3 非会員 株式会社数理設計研究所（テ373-0019 群馬県太田市吉沢町太田リサーチパーク 1-101）

4 正会員 工博 群馬大学工学部建設工学科（†376-8515 群馬県桐生市天神町 1-5-1）

5 正会員 博(工) 群馬大学工学部建設工学科（†376-8515 群馬県桐生市天神町 1-5-1）

5 非会員 群馬大学大学院工学研究科建設工学専攻 (T376-8515 群馬県桐生市天神町 1-5-1)
}

3D laser scanner used on this study can not measure the landform under the water. However, the absence of data shows existence of the water in the other. It is important for the elucidation of the deformation mechanism of the riverbed to grasp the landform of the riverbed in detail. In this study, we tried to discriminate the water route from the measured data by using the trimming algorism and reflectivity. The shoal and water route was elucidated by an analysis of the trimming algorism and reflectivity. Some important characteristics of the waters area in measurement data of the landform of the riverbed by the 3D laser scanner were showed

Key Words: 3D Laser scanner, rive bed, water area treatment, reflectivity, water route, shoal

\section{1. はじめに}

レーザプロファイラを河川工学に応用しようとする研 究が昨今試みられている. 従前, 河道内の地形を測定す る手段としては任意の間隔での断面測量に頼らざるを得 なかったが，面的な情報が求められる場合には，労力あ るいは資金面において現実的に困難，もしくは精度に問 題があることが多い. また昨今, 大容量な数值計算が比 較的簡便に実行可能となってきているが，それら数值計 算に用いる初期条件や精度検証の対象としてのデータな どが求められるとき, 実河川における河道内地形のデー タを得ることは難しかった. 著者らは 2 年前より国土交 通省との共同研究である河川懇談会の取り組みの一環と して, 下館河川事務所の協力を得, 鬼怒川における河床 変動の実測を行ってきているが, その中で3D レーザスキ ヤナ(数理設計研究所開発) ${ }^{11,2), 3)}$ とよばれるレーザプロフ アイラを用いた河道内地形の測定を行ってきた ${ }^{4)}$.その中
で出水前後における測定結果の比較検討によって河床変 動過程の考察を行い，また橋脚周りの局所洗掘に関して その変動量分布求めている.レーザプロファイラ自体が 比較的新しい技術であるため，それを用いた河道内地形 の最適な測定方法に関しても依然として模索中であり， また解決すべき課題も多い，その課題の中で最たるもの が水の取り扱いである. 現在の 3D レーザスキャナのシス テムでは水底の地形を測定することは一般的にはできな い. 比較的水深の浅い限られた条件下での測定，もしく は高価・高出力な機材を用いた測定等によって水底部の 地形が測定されたケースはあるが，一般的には依然とし て水底部の測定は難しい.よって現状では得られた測定 データを見ると水が存在するものと思われる領域にデー タが存在しない. 河道内の地形変化を考察するにあたり, その地形を把握することは言うまでも無く重要なことで あるが，もし仮にレーザプロファイラによって水の有無 によらず水底部の地形も一様に測定可能であったとする 
と, 得られた一連の地形データのどの部分に水が存在し たのか，という情報が今度は逆に失われてしまうことに なる. 湖底や海底など，一般的に水域が変化しない場合 にはこのことは問題にならないが, 河道内では水域は出 水時の大規模変動を始め, 日常的にも変化しており，そ の分布を把握することは重要となる. 特に澪筋形状の把 握は, 河道内地形の変遷過程を考察する上で非常に重要 なものである.

本研究では, 現状の3D レーザスキャナによる測定シス テムの欠点ともいえる水底部の測定が不可能であるとい う点を, 逆に水域の識別機能と捉え, そのデータ特性を 検討し, 測定データから澪筋等の水域を抽出する方法を 提案する. これらの知見は, 今後水底部の地形測定を可 能とし，さらに砂䃯や植生を自動識別するシステムの構 築を行う際に, 河道内地形の測定に適したアルゴリズム を構筑するための知見となるものであると考えている.

\section{2. 現地钼測の概要}

測定の対象としている鬼怒川は全国的にも河床の低下 が著しい河川であり，その対策は急務である. 去る平成 15 年 8 月 9 日, 鬼怒川は台風 10 号による出水に見舞われ ている. 流量は $1,000 \mathrm{~m}^{3} / \mathrm{sec}$ 程度であり, 出水規模として は小〜中規模であり特に大きなものではない．しかしな がら, 結果として過去のより大規模な出水と比べ, 澪筋 が大きく変動した. 表一1に, 鬼怒川における過去 3 年間 の出水および著者らの測定の履歴を示す.

表一1 鬼怒川における過去5年の出水および測定の履歴

\begin{tabular}{|c|c|c|}
\hline & 出水(流量? /s) & 測定 \\
\hline$H 13 / 9$ & 台風 15 号出水(2400) & \\
$H 13 / 12$ & & 第1 回測定 \\
\hline$H 14 / 7$ & 台風 6 号出水(2800) & \\
\hline$H 14 / 8$ & & 第2 回測定 \\
\hline$H 15 / 8$ & 台風 10 号出水(1000) & \\
\hline$H 15 / 8$ & & 第3 回測定 \\
\hline
\end{tabular}

平成 14 年 7 月の台風 6 号出水は大規模なものであり, 川島地区では警戒水位を超え，危険水位に残り $7 \mathrm{~cm}$ に迫 る出水となった. 随所に洗掘・堆積が引き起こされ，河 道内の地形は大きく変化した. しかし大道泉橋直上流で 右岸側より迁回してきた澪筋が橋の中央部から左岸側に かけて流れ込み，またその上流約 $400 \mathrm{~m}$ 付近では左岸沿い を流れていた澪筋と合流する, といった, 澪筋の全体的 な構造には大きな変化は無かった. 写真—1 よび写真—2 にそれぞれ台風 6 号出水前後の大道泉サイト利根川合流 点より上流約 $55 \mathrm{~km}$ 付近, 大道泉橋上流側約 $1 \mathrm{~km}$ 四方)の 様子を示す.また, 図—1 に大道泉サイトの模式図を示す.

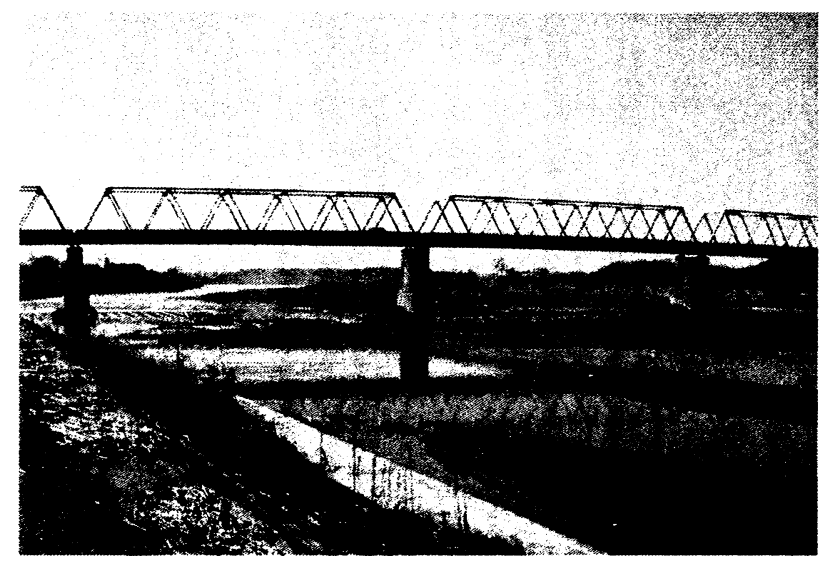

写真一1 大道泉サイト(平成 14 年台風 6 号出水前)

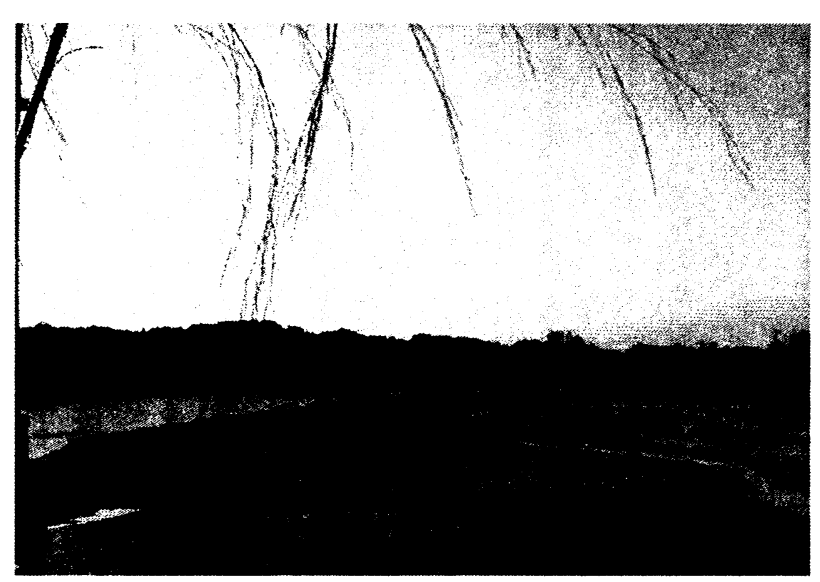

写真一2 大道泉サイト(平成 14 年台風 6 号出水後)

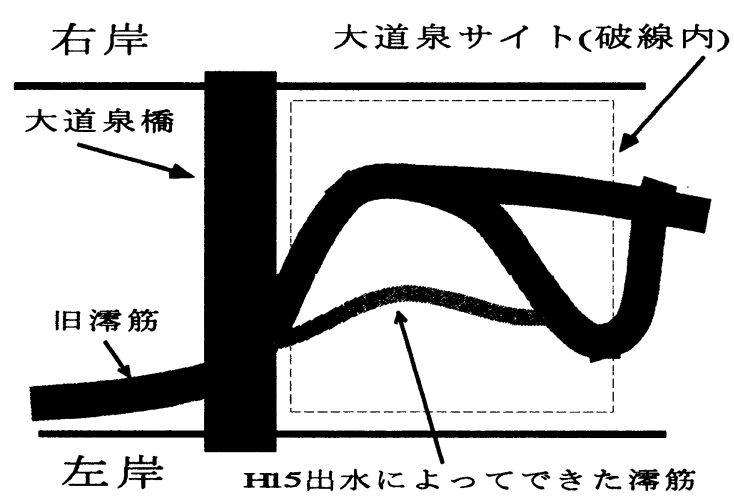

図一1 大道泉サイトの模式図

写真—1 は大道泉橋上流左岸側より下流方向, 写真一2 は大道泉橋の左岸端より上流方向の様子をそれぞれ撮影 したものである. いずれも右岸側に大きな澪笳がある. 図一 2 および図一 3 にそれぞれ平成 14 年台風 6 号出水前 後の 3 Dレーザスキャナによる測定(表一1, 第 1 および2 回測定)結果を示す. 3DLS の測定は測定地点から水平・ 鉛直に一定の刻み角度で回転させながらレーザ到達距離 を測定していくものであり, 図の点群はそれを水平面上 の標高データに変換した際のデータが得られた座標の分 布を示すものであり, ここではデータの無い空白部分を およその澪筋とみなすことにする. 


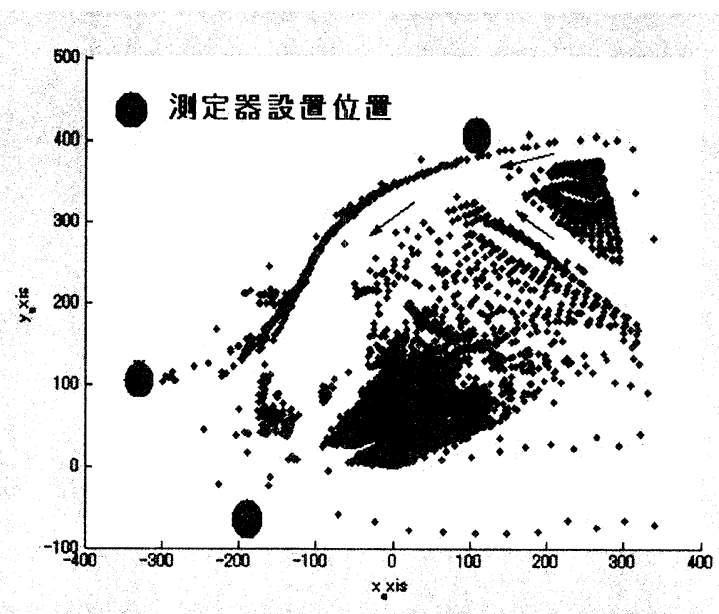

図?2３D レーザスキャナによる大道泉サイトのデータ 測定座標の分布(台風 6 号出水前)

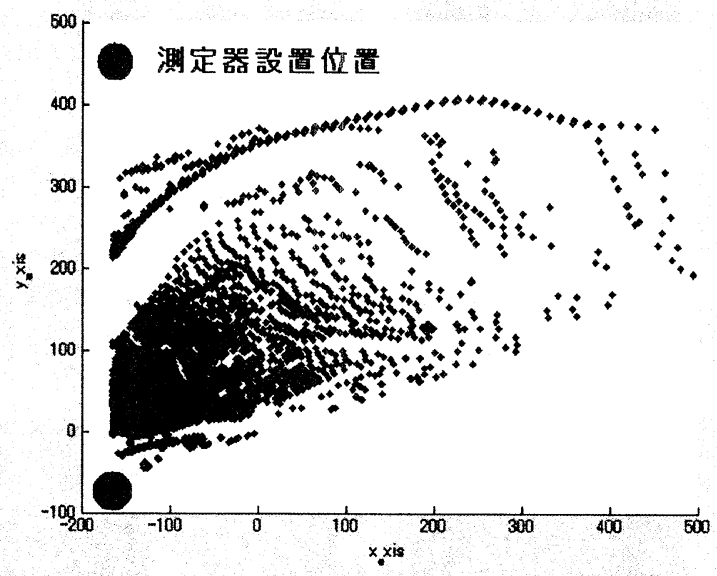

図?3 3D レーザスキャナによる大道泉サイトのデータ 測定座標の分布 (台風 6 号出水後)

図一2および図-3 ともに左側が下流側, 右側が上流側で あり，縦横の座標単位は $\mathrm{m}$ である．図中には見えないが 横軸約-200m の位置に大道泉橋があり, 図は大道泉橋上 流の様子である. 図-2 2 は 3 箇所, 図一 3 は 1 箇所の図中 「測定器設置位置」からの測定を行ったものである. そ れぞれ橋の直上流部では右岸側に沿っていた澪筀が橋中 央部一と流れ込んでいるのが見て取れる.図-3 では測定 ポイントが左岸側 1 点のみであるため右岸上流側のデー タが不足しているため判然としないが，橋上流側約 $400 \mathrm{~m}$ 付近の位置で澪筋が合流している形状であった. これら の計測結果に関する考察は前報 ${ }^{4}$ に譲る. 写真—3に平成 15 年 8 月の台風 10 号出水後の同サイトにおける様子を示 す. 写真— 3 は大道泉橋上から上流側を撮影したもので, 写真右端が左岸である. 写真には写っていないが，右岸 側には従前の澪筋も存在している. 写真右上部付近の遠 景に見える植生帯を迂回するような新たな澪笳が左岸に 沿って出現している. 比較的小規模な出水で大きな変動 がみられ，これらのメカニズムの解明には非常に興味が 持たれるが, 本研究では実地形の把握を目的とした.

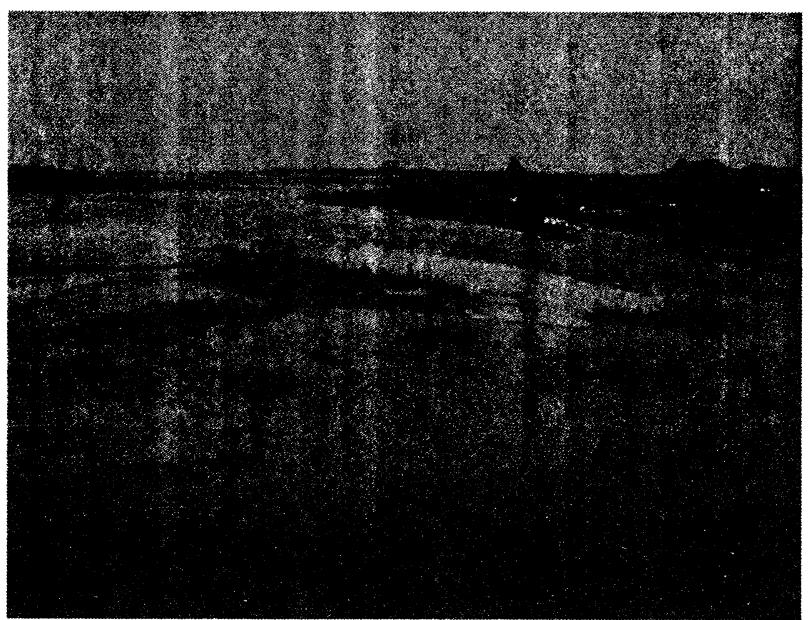

写真—3 大道泉サイト(平成 15 年台風 10 号出水後)

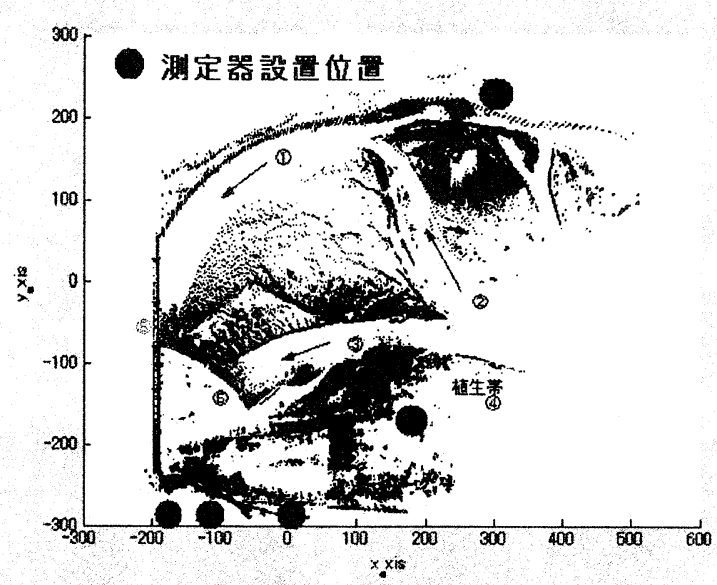

図?4 3D レーザスキャナによる大道泉サイトのデータ 測定座標の分布 (台風 10 号出水後)

図-4に, 3D レーザスキャナによる，この平成 15 年 8 月における台風 10 号出水後の地形測定の結果を示寸. 図 中の点は, 図一 2 および図— 3 同様, 測定によって標高デ 一タが得られた座標を意味している. なお，この図一4 は後述の水域データの処理を既に施したものである．図 の左側が下流側，右側が上流側であり,横軸で-200 の断面 に見えている直線分布のデータ群が大道泉橋の上流側形 状である. 測定は左岸側 4 点および右岸側 1 点の計 5 点 から行った. 3 点からの測定を行った図—2や 1 点からの みの測定によって求めた図一 3 と比較するとより詳細に データが得られていることが伺える. しかしながら前述 のとおり河道内の形状はかなり複雑になっている。.まず, 図一2 および図—3 中にも見られた右岸側に沿う大きな 澪筋は,図中(1に示したように依然として存在している. また左岸側から図中(2)で示した澪筇が合流している様子 も伺える. 最も大きな変化は(250,-50)付近から図中(3)で示 した新たな比較的大きな澪筋が分岐していることである. (300,-150)に(4)として「植生帯」と示しているが, この位 置に分布する植生帯の存在が今回の大きな澪笳変遷に寄 
与した影響が強いものと推察される. (4)の植生帯付近に データが存在しないが，これは植生の遮蔽効果によって レーザが到達しないためである. (3の澪筋左岸形状より 左岸側の空白部分は全てこの植生および極端な起伏によ る遮蔽効果によってデータが得られなかった領域であり， 水の存在を示寸ものではない.このような明らかに水域 と陸域の区別ができる場合は問題ないのであるが, 図一4 中には視覚的には判別しにくいデータが現れている. 図 中(5)（6)の位置に示した(3)の澪笳を遮るような湾曲した 形状である.このような陸域が澪筋を遮るように存在す ることは考えにくいし，無論現地調查の際にも確認して いない. 考えられるのは浅瀬である. 写真一3の下部がち ようどこの図 4 中の(5)の辺りに相当するが, 確かに一見 一様に水域と見える領域にも浅瀬が数箇所に存在してい るようにも見受けられる.

今回の測定ではもう 1 つ水面の存在に起因する特徵的 なデータが得られた. 前述したが, 3DLS の測定は測定地 点から水平・鉛直に一定の刻み角度で回転させながらレ 一ザ到達距傩を測定していく. その結果得られるのは測 定地点より，ある俯角をもって斜めから見た座標系にお ける到達距離のデータである. そのデータを平面座標上 の標高データに変換したものが, 例えば図一4のような図 である. 図一 5 に座標変換前の, 水平・鉛直角座標系にお ける到達距離を測定した座標分布図を示す.図一4におい て横軸で-200〜0, 縦軸で-200〜200 ほどの領域に対応し ている. 前述でふれた浅瀬が図中下部中央にある. デー タの得られている部分が白く, 無い部分が黒く表示され ている. 図中丸く囲んだ部分の右岸側澪筋ひ水表面に橾 景の形状が映し出され白く表示されており，水面である にもかかわらずデータが得られていることが伺える. 写 真一4に, それにほぼ対応する付近の様子を示す.

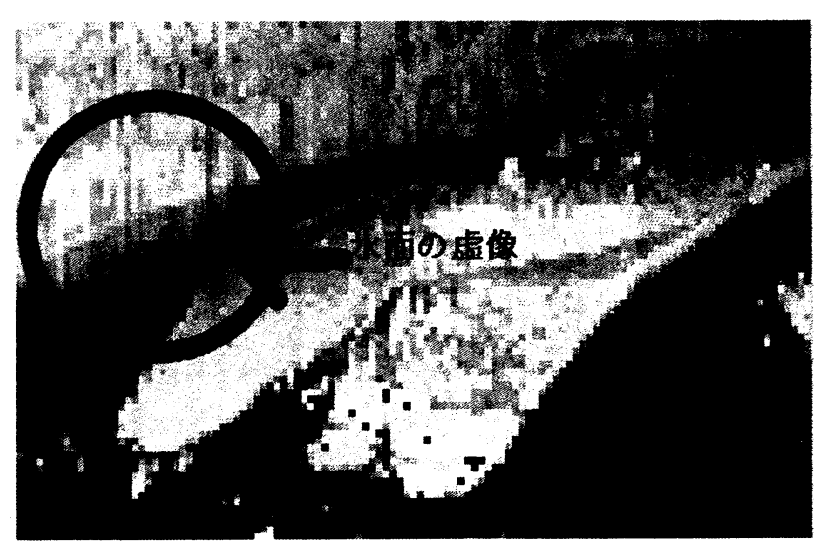

図—5 座標変換前の測定座標分布

図—5 の座標軸では，水平角 $0.5^{\circ}$ ，鈆直角 $0.05^{\circ}$ と測定 の角度刻みが異なるため, 図一 5 の段階では綐横の縮尺が 異なる. よって比較用の写真 4 も図—5 と同様のスケー ルに縮尺を変えてある. 写真右側に左岸側の澪筋があり,

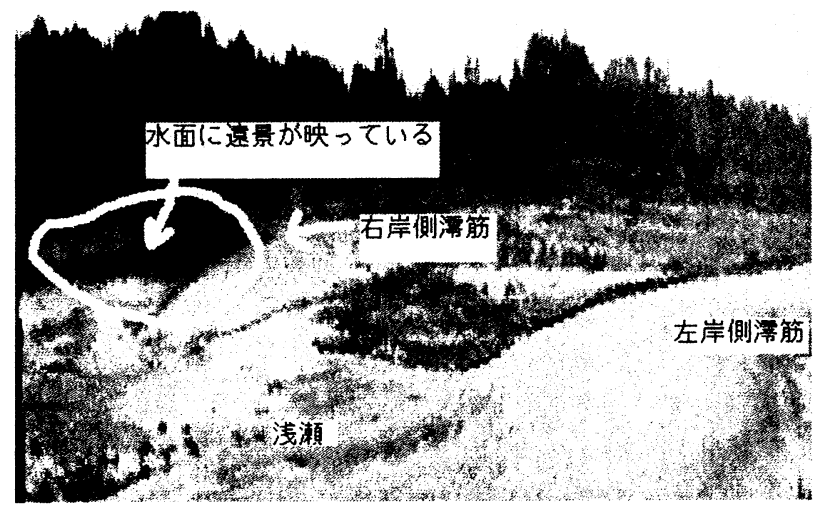

写真—4 遠景を映す水面の様子

中央部の砂洲を挟んで対岸, 写真左側に右岸側澪筋が見 えている. 問題はこの右岸側澪笳の水面に遠景の樹木の 影が映っている部分である. 図一5をみるとこの部分にデ 一タを計測しており，一見流路を遮るように陸域が存在 しているように見える. 澪筋の抽出にあたってはこの部 分の取り扱いが必要となる. 以下でこれら 3D レーザスキ ヤナによる測定結果中に現れる水域データの特徴とその 取り扱いに関して考察を行い，全体的な澪筋抽出のアル ゴリズムの構築を試みる.

\section{3. 水域の取り扱い}

\section{（1）水面の虚像}

まず，前述の水面に写る遠景の虚像データの取り扱い に関して検討を行う. 今回このようなデータが得られた 要因としては, 俯角が小さいこと，および䞦景に高い樹 木が存在したことが挙げられる.図一6に水面におけるレ 一ザの反射と虚像の誤測定の模式図を示す.水面で反射 したレーザは図一 6 中の点線で示したように入射角で反 射し，遠方にある樹木などの対象を捉えてしまう. その ため水面と思しき部分にあたかも陸域が存在するように 見えてしまうのである.この誤測定に対して本研究では 公開中の特許アルゴリズムを応用することでデータの修 正を試みる. すなわち俯角の上昇に伴って得られる距離 では减少しない, というものである. 基本的にレーザ照 射の俯角が上昇すればその分遠方を捉えることになるの で測定される距離は増加する．直立壁等でさほどの増加 がない場合もあるが減少することはない，俯角の増加に 伴って距離が減少する場合にその部分を除去するという ものである.これらはそもそも陸域の樹木帯を除去し陸 地の形状を抽出する際に用いられるものであったが, 樹 木ではなく水面の反射によっても同様の測定結果となる ことが分かった. 図一 6 中の点線の距離は本来測定したい 水面までのものではなく. 遠方水面での反射を経由した 遠方の樹木までの距離となっている. 図中の実線で示し た陸域は正常に測定されるので距離 11 は水面より遠方の 陸域までの測定距離 12 よりも大きくなっている. 
測定位置の近傍 : 11

測定位置の遠方 : 12

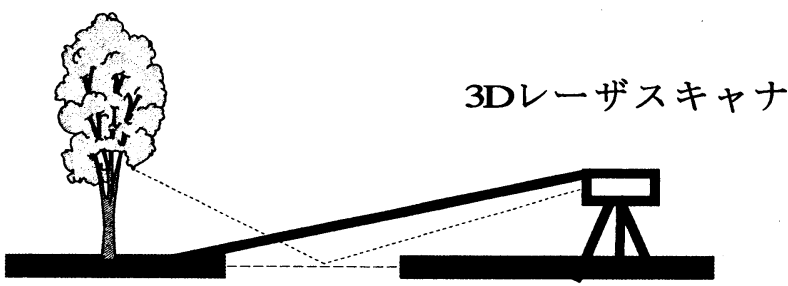

陸地 水面

図-6 水面でのレーザの反射と虚像の䛊測定の模式図

図一5 の澪筋上にデータが存在する領域の断面を抽出 し，その断面における低水路右岸までの距離の測定結果 を図一7に示す.図中測定距離と示したものは実際の測定 結果, $\mathrm{A} \sim \mathrm{E}$ の各点とそれら各点を結ぶ線分は説明のため の模式的なもの，および算出された水面の位置である.

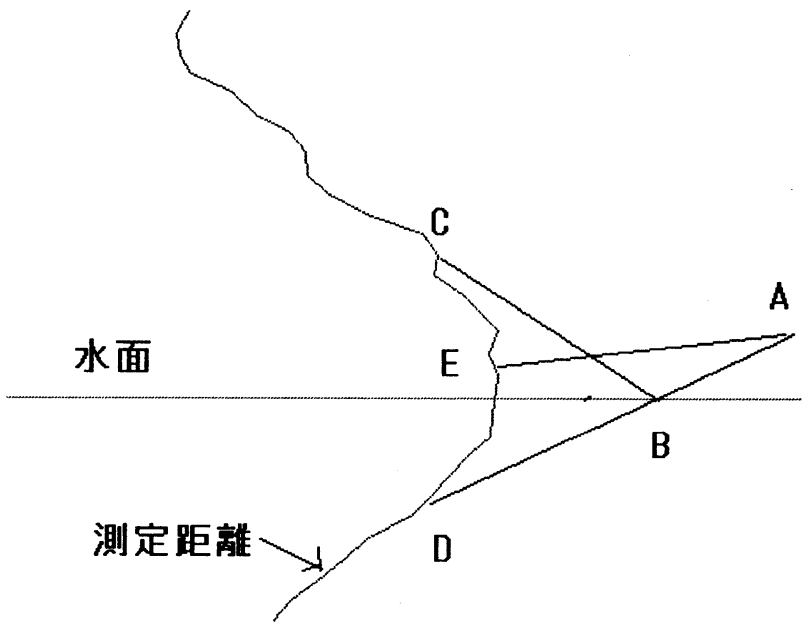

図一7 右岸側澪筋の右岸までの測定距離の断面図

A の位置にある 3D レーザスキャナからのレーザは本 来 B の水面までの距離を測定するために照射されたもの であるが水面で反射することによって遠景の C 地点の地 形を捉えてしまう．そのためそのままこれを距離に換算 するとこの角度で照射されたレーザが捉えた対象までの 距離は $\mathrm{AB}+\mathrm{BC}$ であるので, $\mathrm{D}$ の位置に測定対象が存在 しているように見える. 俯角を上昇させた測定では正常 に $\mathrm{E}$ 地点まで距離を捉えるので, この右岸側低水路の右 岸形状は図中の測定距離と示したラインのようになる. そこで $\mathrm{E}$ 地点付近の測定距離が極值を持つ部分を水面と し，それ以下の部分を虚像の誤測定として除去するので ある. このアルゴリズムは実際にオーバーハングしてい る地形を消してしまうものであるため，その適用には注 意を要する. 今回対象としている領域に関しては問題な
いことを確認しているが，河岸がオーバーハングするこ とは珍しくないだけに，今後それらを統一的に扱えるよ う，さらにアルゴリズムを改良する必要がある．これら のアルゴリズムを用いて水面の虚像による誤測定を除去 したものが図一 4 に示した平面図である.

\section{(2)浅瀬}

次に図-4 の(5)〜6付近に見られる澪筋を遮断するよ うな地形について考察を行う. 写真-4の下部中央付近が これにあたり，浅瀬が存在することが分かる. 現状の 3D レーザスキャナによる測定システムでは, 本研究のよう に俯角の小さい条件での測定においては，基本的に水面 では反射を起こしデータを得ることができない，前述の 水面反射による虚像の誤測定はその例外である. しかし 浅瀬では波立つ水面や見え隠れする河床，そして浅い水 深などの条件によって，データが取れてしまうことがあ るため，一見そこに陸域が存在するように見える。，一旦 それが陸域と判定されるとこれまでは他の完全な露出部 と区別ができなかった。 しかしながら澪筋を抽出する際 にはそれらの領域を他の領域と区別し，流れが存在する 浅瀬として取り扱うことは重要である. 本研究では測定 の際に得られる反射率をパラメータとした浅瀬の識別を 試みる. 3D レーザスキャナでは照射したレーザと受け取 る反射光の比によって反射率を計測している. 図一8に, 図一 5 に対応するデータの反射率の等高線図を示寸。

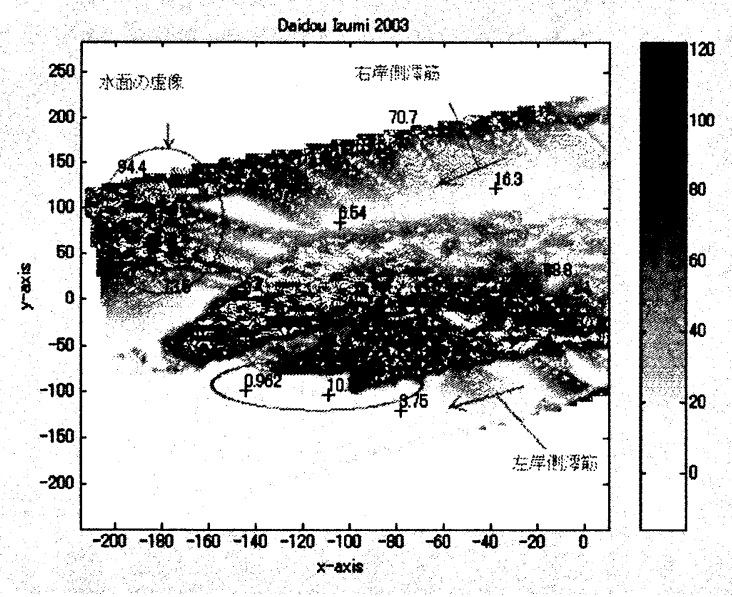

図一8 反射率の等高線図

同様に図の右側が上流側，左側が下流側である．図の 中央やや上部に右から左方向に右岸側の澪筀が見えてい る. 横軸で-160, 縦軸で 50 付近に前述の水面に映った遠 景の虚像データによるものと思われる高い反射率が現れ ているのが分かる. 右下付近に左岸側の澪筋の一部が見 えている. その流れの先横軸で-140, 縦軸で-100 辺りが 問題の浅瀬であるが，反射率が急激に落ちていることが 分かる. 反射率は0〜255 の值で表現されており, 図一8 中では完全に露出している陸域において最大で約 120 程 
度の值である. 問題の浅瀬部分では 1 ケタから 10 程度で あるので,およそ陸域の1割程度の反射率となっており， これによって一見一様な陸域のように見えるデータ群を 通常の陸域と浅瀬に分離することが可能であると思われ る. 測定領域全般に渡りこの反射率によって陸域と浅瀬 を分離すると，およそ図一9 のようになった. 図の下側 に左岸側の植生帯が示してあるが，それより上部の黒い 部分が陸域, 白い部分が水域である. 浅瀬は 1 4 の番号 を付して示してある. (1)および(2)の部分の浅瀬では 10 程 度, (3)および(4)の浅瀬では 30 程度の反射率であった. (3) および(4)に関しては水域であることは確認しているが, 極端に低い反射率であるといえるかどうか疑問もある. 条件によっては 30 程度の反射率を示す陸域も存在する からである. また，右岸側粉朌は図中の対岸形状にそっ て澪笳が存在することを確認しているが，それが再現し きれていない.ここでは(3)の部分を浅瀬として識別する だけでは不十分なようである。

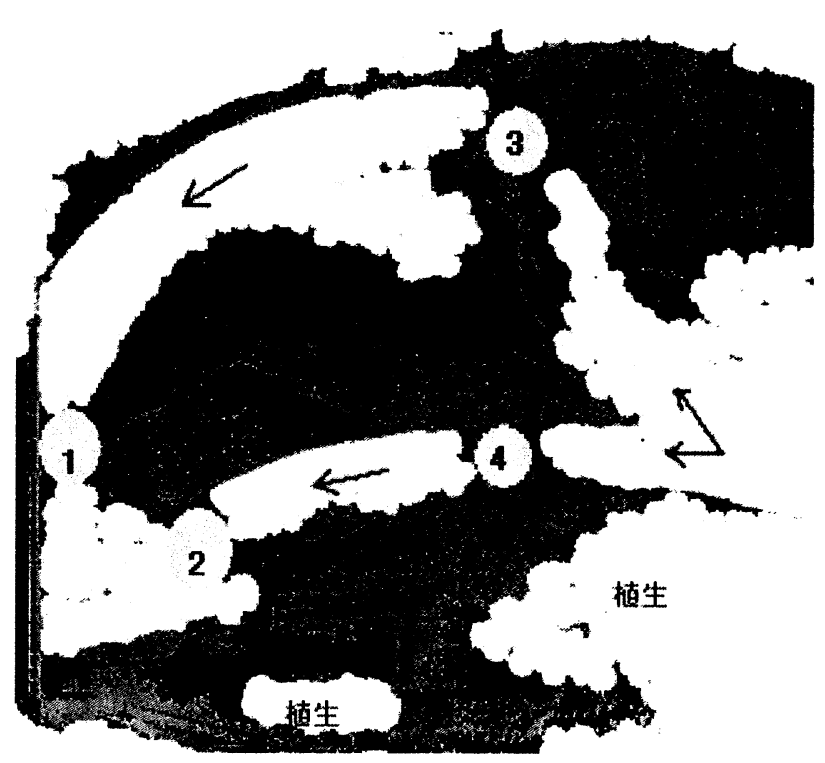

図一9 反射率フィルターによる澪筋の抽出

閵值を高くすることによって不足分の水域を浮かび上 がらせることは可能であるが，それに伴って陸域も削除 されていくため、その設定には慎重を要する.これらは 今後さらにデータを蓄積し検討を進めていく必要がある. しかしながら，図一9 を見ると，事前に植生帯と分かっ ていた領域以外に関しておよその澪筋形状は抽出できて いるものと思われる.

\section{4. まとめ}

以上, 本研究では, 現状の3D レーザスキャナによる測 定システムの, 照射レーザが水面で反射し測定が不可能 となるという特徴を用いて, 河道内地形に対する測定結 果から澪筋や浅瀬といった水域を抽出するアルゴリズム
を検討した. 以下に, 本研究で得られた主な結果を示す。

（1） 3D レーザスキャナで河道内地形を測定した場合， 基本的には遮蔽物によって測定できなかった部分を 除き, データの無い部分が水面となっている.

（2）測定の俯角が小さく遠景に比較的高い物体が存在す る場合には，照射レーザが水面で反射し遠景の物体 を唄測定することによって本来水面域であるはずの 部分にデータを測定してしまうことがある.

（3）水面反射による誤測定は俯角上昇に反して距離が減 少する領域を捉えることによって除去することがで きる. 測定距離の極地が水面と考えられるが，もと もとオーバーハングしている地形には適用できない．

(4) 陸域として測定されているデータの中には反射率が 極端に低い部分があり, 本研究においては浅瀬がそ れにあたる. 反射率データは種々の測定条件(測定日 の天候等)によって変化することが予想されるため, 最適な閾值の特定に関しては, 今後さらにデータ収 集と検討が必要である.

(5) 水面反射による誤測定データの除去および反射率パ ラメータによる浅瀬の抽出によって, 河道内地形デ 一タ中のおよその水域を把握することができた.

謝辞 : 本研究は, 国土交通省下館河川事務所との間で進 められている鬼怒川を対象とした河川懇談会共同研究の 一環として行われたものである.ここに記して関係各位 に謝意を表します。

\section{参考文献}

1）藤永清和, 名倉裕, 永島明: 大西山崩壊地の $3 \mathrm{D}$ モ デル作成, 平成 13 年度砂防学会研究発表会概要集, pp.394-395, 2001.

2）藤永清和, 名倉裕 : レーザスキャナによる地形の形 状測定, 平成14年度砂防学会研究発表会概要集, pp.276-277, 2002.

3）数理設計研究所, http://www.madlabo.com/mad/

4）松本健作, 名倉裕, 玉置春朗, 小葉竹重機, 清水義 彦, 秋山圭史郎 : 3D レーザスキャナによる鬼怒川 の河道内地形の実測とその河川工学的応用, 河川技 術論文集, Vol9, pp.253-258, 2003.

5）安田浩保, 武富一秀, 舘健一郎, 金木誠 : レーザス キャナにより取得した数值標高情報に基づく河道 形状情報お作成に関する研究，河川技術論文集, Vol.9, pp.247-252, 2003. 